\title{
BUILDING FINANCIAL AND INSURANCE RESILIENCE IN THE CONTEXT OF CLIMATE CHANGE
}

\author{
Miroslav Miškič ${ }^{1}$, Goran Ćorič², Danijela Vukosavljeviç ${ }^{3}$
}

\begin{abstract}
Summary
The key challenge for individuals, businesses and governments would be the building financial and insurance resilience in changing climate. It becomes important issue for the financial management to create financial protection and insurance means to manage the financial losses, reducing the economic impact of disaster events, and supporting better recovery. In accordance with that the Paper provides an overview of the field and desk research of potential income implications of climate change for the financial management of disaster risks and losses. Desk research is based on Serbian case and its experience with the 2014 floods. Key findings of the field research provided in Serbia in 2016 on managing the risk of natural disasters, floods, fires, earthquakes as a part of organizational risk in 92 manufacturing firms, banks and insurance companies is also provided in the Paper. The methods used are: statistical description, X2 test and liner regression models. The results of both researches on risk management of floods showed that: companies calculate the impact of this risk to their year revenues as small, also a non-strategic approach of the Serbian government can be seen, as a financial gap of 65\% in covering the losses. The research results pointed also to low awareness of the problem on the corporate and national level. The contribution of the Paper is to support further development of country and local plans for more effectively reducing the economic disruption of disaster events and policy approaches to supporting the penetration of disaster finance and insurance coverage and the capacity of insurance markets to absorb these risks. Also, to support the improvement of the culture of risk management of business sector in this field.
\end{abstract}

Key words: Risk management, flood risk, banking, insurance, climate change

JEL: G31, Q54, G21, H84, G22.

1 Miroslav Miškić Ph.D., Assistant Professor, Faculty for Technical Sciences, Trg Dositeja Obradovića no. 6, 21000 Novi Sad, Serbia, Phone: +381 65511 233, E-mail: miroslav. miskic@,outlook.com; sme_rada@hotmail.com

2 Goran Ćorić, Singidunum University Belgrade, Department for doctoral studies, Danijelova street no. 32, 11000 Belgrade, Serbia, Phone: +381 63264 496, E-mail: coric.g7@gmail.com

3 Danijela Vukosavljević Ph.D., Assistant Professor, Faculty for management, FAM, Njegoševa street no. 1a, 21205 Sremski Karlovci, Serbia, Phone: +381 622096250 , E-mail: dr.danijela.vukosavljevic@gmail.com

EP 2017 (64) 3 (1019-1033) 


\section{Introduction}

Among the key implications of climate change is its expected impact on the severity and frequency of disaster events. Disasters present a broad range of environmental, financial, economic, social, and human impacts with long lasting effects. Through the direct damages they cause to buildings, equipment and infrastructure as well as through indirect consequences such as business interruption, loss of employment and output and decrease tax revenues, besides human suffering. A number of studies have attempted to calculate the possible impacts of climate change on disaster losses for different regions based on specific climate change scenarios. The financial management of these impacts is a key challenge for individuals and governments. Risk management in companies, manufacturing, banking, insurance and risk transfer tools-reinsurance and capital markets - catastrophe bonds, could provide financial protection by providing a means to manage the financial losses, reducing the economic impact of disaster events, and supporting recovery.

Initiatives to improve risk awareness for flood and other disaster insurance coverage cold establish a sufficiently large pool of disaster risks. As losses increase in the context of climate change, governments may also need to examine impediments to the supply of insurance, such as a lack of the necessary data for risk pricing, limited financial and technical capacity in the insurance sector, insufficient management of disaster risks, as- land use planning, protective infrastructure, or limited access to reinsurance coverage, including any significant impediments to accessing international reinsurance markets. Financial support from governments, donors may be necessary to overcome some of these impediments or share some of the risk. The management of these impacts requires careful consideration of options for mitigating the impact of such events, such as measures to reduce exposure, enhance emergency preparedness to minimize disruption and address financial impacts through the use of risk transfer tools. Also insurance can contribute directly to reducing overall losses by encouraging risk reduction with involving the: risk based premiums for insurance coverage and premium discounts for effective risk reduction measures can provide incentives for reducing risks by offsetting the costs of risk reduction measures with lower future premiums for insurance coverage. Risk reduction measures implemented policyholders.

Despite the postured impact of insurance on mitigating the impact of disaster events, a significant insurance gap remains, particularly in developing countries as Serbia is, in terms of the share of the economic losses form disasters that are covered by insurance. Las decade insurance covered approximately $51 \%$ of all losses in high income countries, but less than $10 \%$ of losses in developing countries what further creates large fiscal exposures to disaster risks given the expectation that governments will compensate uninsured private losses (Melecky, Raddatz, 2011).The insured losses have no statistically significant impact on long term autput, while uninsured losses come with additonal macroeconomic costs, amountin to a cumulative output cost over 10 years of more than 2,5\% ( von Peter et al., 2012).

In Southeast Europe, with the support of the World Bank and EU countries have collaborated on the establishment of Europa Re as a means of encouraging the development of local catastrophe insurance markets, building reinsurance capacity, infrastructure services and 
technology solutions. So, a sophisticated web based production platform was provided in 2014 in member states offering disaster insurance product in their markets. In 2015, the OECD published Disaster Risk Financing: A Global Survey of Practices and Challenges which provides an overview of the disaster risk assessment and financing practices of a broad range of economies relative to the guidance elaborated in G20/OECD Framework for Disaster Risk Assessment and Risk Financing.

The Financial Management of Flood Risk extends this work by applying the lessons from the OECD's analysis of disaster risk financing practices and the development of its guidance. The OECD Secretariat prepared the report based on input provided in response to an OECD survey questionnaire as well as research undertaken by the OECD and other international organizations.

Figure 1. Integrated Approach to Flood Risk Management

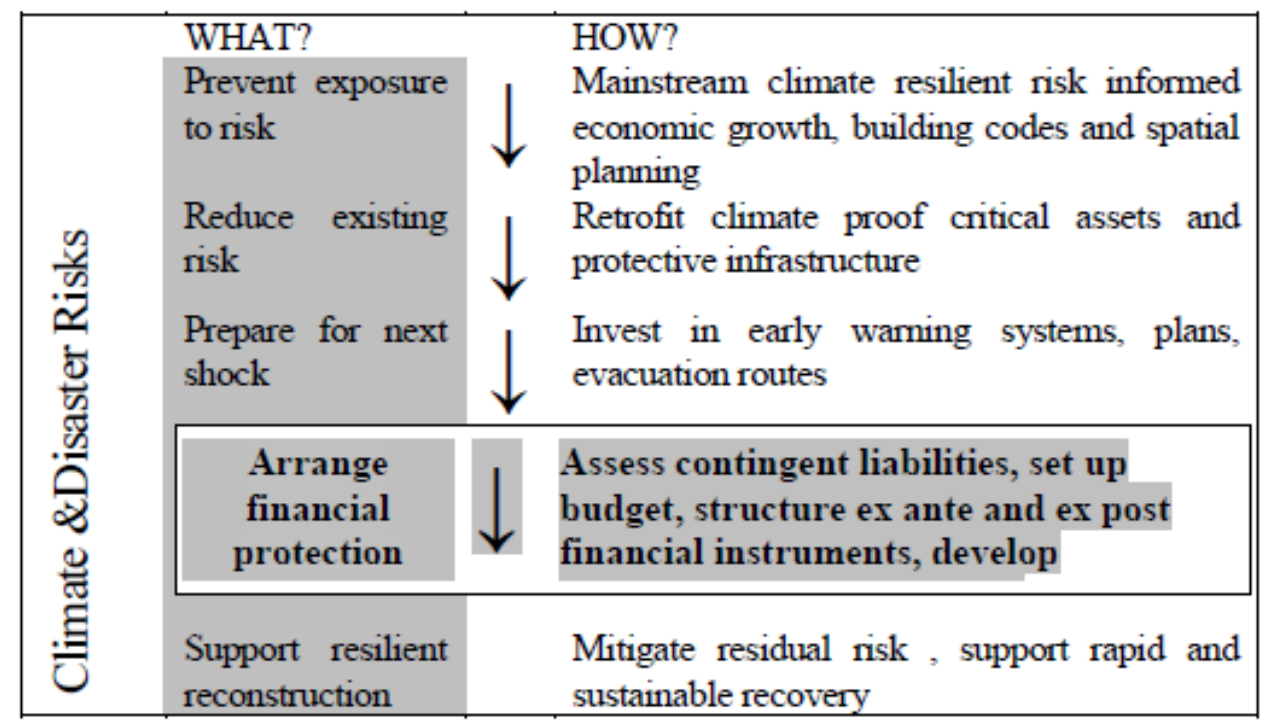

Source: World Bank, 2016;

The report provides an overview of the approaches that economies facing various levels of flood risk and economic development have taken to managing the financial impacts of floods. The report benefited from the support and input of the OECD High-Level Advisory Board on the Financial Management of Large-Scale Catastrophes and the OECD Insurance Committee. For many countries the financial management of flood risk presentsa policy challenge, seeking for investments in risk prevention and public awareness and the use of risk transfer tools to protect against significant post-disaster costs.

This paper willing to contribute to encouraging risk management awareness provides an overview of the implications of climate change, floods for the financial management of disaster risks. 
Based on literature and theoretical background of risk management in the field of climate change, it presents the key findings of desk research on flood disaster in Serbia happened in 2014, and field research on attitudes of 92 manufacturing companies, banks and insurance companies on their risk management practices in managing organizational risk concerning floods, and other disaster. It also in the part of discussion and conclusions provides main issues and suggestions for further research. At the end is given the literature used in the Paper.

\section{Review of the scientific literature}

Definitions of flood risk

There are numerous definitions of risk. For the purpose of the paper the risk is consider to be the function of the hazard, exposure and vulnerability. Further impacts in specific field of flood (Kundzewicz et al., 2014) the risk is the function of the flood probability, exposure and vulnerability (Figure 2.).

Figure 2. Flood risk

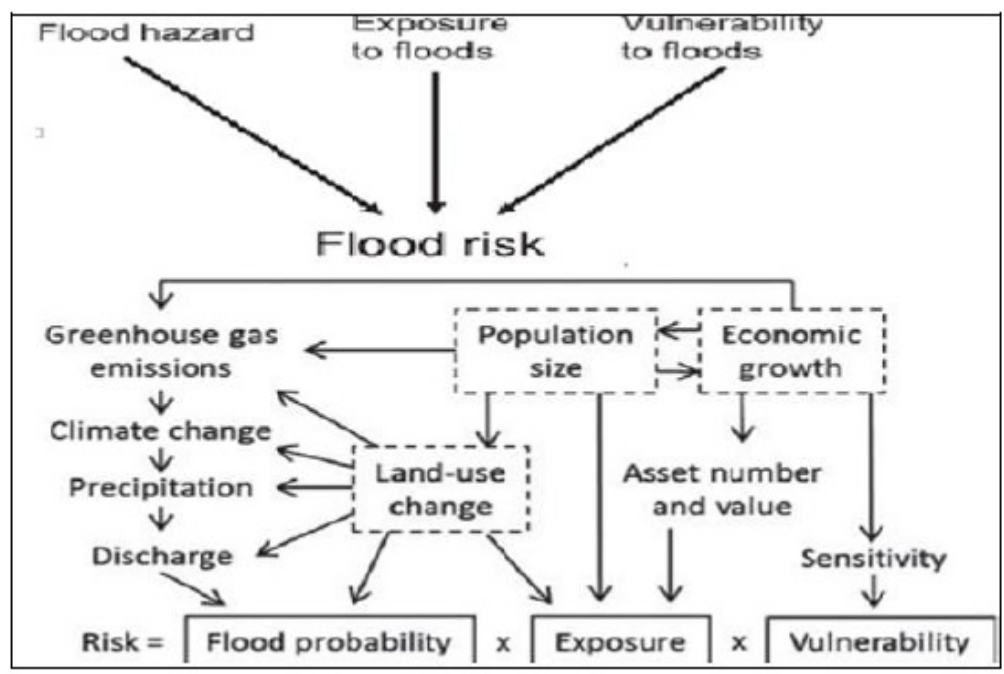

Source: According to Kundzewicz et al., 2014;

In the theoretical discussions on better understanding floods, changes in environmental conditions, influences on flood peak and wave propagation, changes in land use and creation of loss potential can be made a choice of articles (Table 1.)

Table 1. The flood literature review

\begin{tabular}{|l|l|}
\hline Author (s) & Summary \\
\hline CDC, 2000; & Public health surveillance and medical record review \\
\hline Rashid, 2000; & Qualitative survey \\
\hline Ogden et al., 2001; & $\begin{array}{l}\text { Surveillance and record review of disaster-area hospitals and patient } \\
\text { visits }\end{array}$ \\
\hline Yale et al., 2003; & Case-control study of vehicle crashes with drowning \\
\hline
\end{tabular}




\begin{tabular}{|l|l|}
\hline Author (s) & Summary \\
\hline $\begin{array}{l}\text { Cariappa and Khanduri, } \\
\text { 2003; }\end{array}$ & Assessment of flood-related illness/injury in care seekers \\
\hline Baxter, 2005; & Descriptive/historical account \\
\hline Gerritsen, 2005; & Descriptive review / historical account \\
\hline Beyhun et al., 2005; & Review of the impact of flooding in Turkey from 1970 to 1996 \\
\hline Guzzetti et al., 2005; & Review of flood in Italy from 1279 to 2002 \\
\hline $\begin{array}{l}\text { Jonkman and Kelman, } \\
\text { 2005; }\end{array}$ & $\begin{array}{l}\text { Examination of the causes and circumstances of 247 flood disaster deaths } \\
\text { across 13 flood events in Europe and the US }\end{array}$ \\
\hline Jonkman, 2005; & $\begin{array}{l}\text { Review of mortality from river floods from 1975 to 2002 using the } \\
\text { CRED Database }\end{array}$ \\
\hline Tarhule, 2005; & $\begin{array}{l}\text { Review of newspaper accounts of rainfall and rain-induced flooding in } \\
\text { the Sahel savanna zone of Niger from 1970 to 2000 }\end{array}$ \\
\hline Ahern et al., 2005; & $\begin{array}{l}\text { Review of studies of global flood events and assessment of gaps in } \\
\text { knowledge relative to reducing public health impact of flooding }\end{array}$ \\
\hline Lastoria et al., 2006; & Italy,1951 to 2003 review of flood deaths and socioeconomic impacts \\
\hline Llewellyn, 2006; & Review recent floods events \\
\hline Pradhan et al., 2007; & Household survey in flood affected areas \\
\hline Spencerand Myer, 2007; & Descriptive/historical account \\
\hline Schnitzler et al., 2007; & Telephone survey of flood affected households \\
\hline $\begin{array}{l}\text { Jonkman and Vrijling, } \\
\text { 2008; }\end{array}$ & $\begin{array}{l}\text { Review of mortality attributed to different flood types and presentation of } \\
\text { new method for estimating flood related deaths in low-lying areas }\end{array}$ \\
\hline Jonkman et al., 2009; & Secondary data analysis of following hurricane Katrina \\
\hline FitzGerald et al., 2010; & Review of flood fatalities in Australia from 1997 to 2008 \\
\hline Biswas et al., 2010; & Household survey of child injury in flood-affected areas \\
\hline Bich et al., 2011; & Cross-sectional household survey \\
\hline
\end{tabular}

Source: Authors;

The most often mentioned types, causes and impacts of floods in the theoretical articles are:

- Coastal floods (sea-borne) mostly caused by wind, high water levels which are generated by a superposition of: astronomical tides, wind setup, external surge, surface waves;

- Lake floods;

- River floods (fluvial floods) generated by: long-lasting rainfall with high depth over a large area, or snowmelt, Infiltration capacity of the soil is exceeded, water converges in the drainage system. Flood wave builds up in the entire system or in principal stream(s). Flooding process: Areas adjacent to the river are affected first. Flooding originates from the river channel. Impact: Flood plains are usually highvalue areas, huge loss potential but, flood control/protection/; prevention is possible (dikes, reservoirs) as measures always paying off in the long run.

- Flash floods (pluvial, off-plain) are one of the most frequent causes of death from natural hazards; 
- Urban flooding, with the high percentage of impermeable surfaces, no space for orderly runoff during intense rainfall, high loss potential;

- Surface flooding, surface runoff (,wild water $\left.{ }^{6}\right)$;

- Mountain floods. Torrent, special type of flash flood with high sediment transport rates, washing off of volcanic ash by intense rain, melting of snow/ice cover during a volcanic eruption, high-viscosity flow, fast, extremely destructive, Sometimes hot, Lahar;

- Groundwater/waterlogging floods, rising groundwater table, local or widespread high rainfall in flat areas, relatively slow onset, long lasting, Interruption of GW flow, seepage underneath a dike „Plum rain“ - very long lasting drizzle-type rain soaks the ground from the surface and thereby seals it. In little or moderately permeable underground situations. Highly damaging to crops;

- Backup floods. Landslide or glacier backs up a river, sudden break-through when natural dam is overtopped, less frequent than in the past due intensive use of rivers (cooling water);

- Breakfloods. Dam break flood, similar to flash floods/debris flows, extreme depths possible, very few large dams have failed in history, hundreds of small dams fail every year;

- $\quad$ GLOF (Glacial Lake Outburst Flood), melting of a glacial icecap during a volcanic eruption;

- Subsidence-caused floods. Man-made causes, groundwater load from reduced pumping buildings sediment input. Natural causes: earthquake isostatic sinking.

\section{Methods and materials}

\section{Key findings on disaster profile 2014, desk research}

Floods in Serbia 2014 affected (Estimates based on the Post Disaster Needs Assessment implemented by the Government of Serbia with the assistance of the WB, UN and EU) 119 municipalities (out of 165) and 22\% of total population. More than 30 municipalities sustained extensive damage, 57 lives were lost, and 32,000 families were forced out of their homes. Production of electricity decreased by $25 \%$, due to the flooding of an open-pit coal mine, a key source of lignite-based power generation. The disaster caused a recession in the Serbian economy, GDP fell by 1.8\% in 2014 as total disaster effects (damages and losses) were $4.8 \%$ of GDP (EUR 1.7 billion). It is estimated that total needs for recovery and reconstruction were EUR 1.35 billion. No adequate system was in place to respond to overwhelming needs in a coordinated fashion, what caused drafting a new set of rules, law and bylaws (Figure 3.) 
Figure 3. Financing of flood relief and reconstruction in 2014

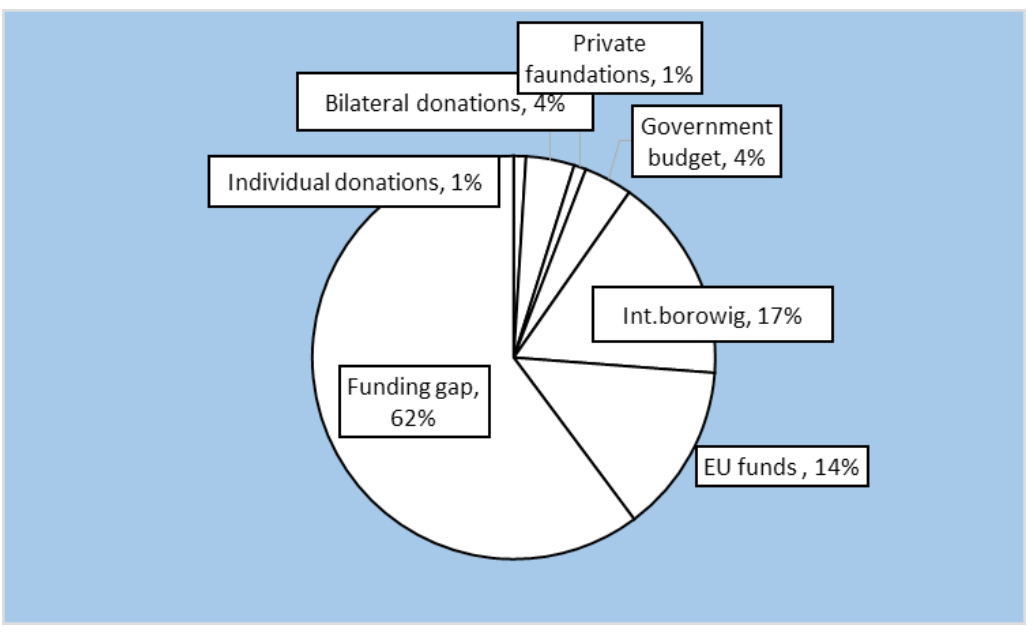

Source: Office for Reconstruction and Flood Relief of Serbia;

Government aid has been concentrated to provision of over 40 million EUR to 20,929 families, 5 million EUR provided to 2006 SMEs as cash grants, aid packages for over 26,000 agricultural households in 29 municipalities affected by floods (saplings, animals, animal feed, equipment), cattle breeders financed from the national budget with full replacement value for almost 5000 farm animals and farmers for 16,000 hectares and reconstruction of energy sector, transport infrastructure, 111 public buildings, 109 projects of local infrastructure (Table 2.).

Table 2. Risk Layering in Serbia

\begin{tabular}{|l|l|l|}
\hline \multicolumn{1}{|c|}{ Disaster risk } & \multicolumn{1}{|c|}{ Financing source available } & \multicolumn{1}{c|}{ Amount of funds available } \\
\hline $\begin{array}{l}\text { High-risk layer(major } \\
\text { floods, major } \\
\text { earthquakes) }\end{array}$ & Donor assistance & $\begin{array}{l}\text { Unpredictable an unreliable (2014 the } \\
\text { total of } € 235 \text { million) }\end{array}$ \\
\cline { 2 - 3 } & Emergency borrowing & $\begin{array}{l}\text { Unpredictable (€227 million drown from } \\
\text { World Bank for 2014 floods emergency } \\
\text { recovery) }\end{array}$ \\
\hline $\begin{array}{l}\text { Medium -risk layer } \\
\text { (regional floods, minor } \\
\text { earthquakes) }\end{array}$ & Contingent financing & $\begin{array}{l}\text { Not currently available (\$100 million } \\
\text { CAT DDO is in early preparation) }\end{array}$ \\
\hline
\end{tabular}




\begin{tabular}{|l|l|l|}
\hline \multicolumn{1}{|c|}{ Disaster risk } & \multicolumn{1}{|c|}{ Financing source available } & \multicolumn{1}{c|}{ Amount of funds available } \\
\hline & $\begin{array}{l}\text { Budget funds: permanent } \\
\text { budgetary reserve }\end{array}$ & $\begin{array}{l}€ 17,00 \text { (originally budgeted, increased } \\
\text { one-off by 2014 supplementary budget } \\
\text { to approximately } € 20 \text { million) }\end{array}$ \\
\cline { 2 - 3 } $\begin{array}{l}\text { Low-risk layer ( localized } \\
\text { floods, droughts, } \\
\text { landslides) }\end{array}$ & $\begin{array}{l}\text { for damage caused by the } \\
\text { natural disasters }\end{array}$ & $\begin{array}{l}€ 700,000 \text { (originally budgeted, increased } \\
\text { of } € 1.5 \text { million) }\end{array}$ \\
\cline { 2 - 3 } & Budget reallocation & $\begin{array}{l}\text { Unclear (10\% of each appropriation } \\
\text { available immediately higher if splintery } \\
\text { budget is passed) }\end{array}$ \\
\cline { 2 - 3 } & Catastrophe insurance & $\begin{array}{l}\text { Very low because of low penetration } \\
(€ 16.9 \text { million paid out for 2014 floods) }\end{array}$ \\
\hline
\end{tabular}

Source: Post Disaster Needs Assessment (2015). Ministry of finance of Serbia;

\section{Key Findings on flood risk management, field research}

\section{Sampling and methodology}

The field research was provided in Serbia in 2016 on the risk management and its importance for companies' sustainability or development. The research sample make 92 surveyed enterprises, classified according to the type of activity they perform: $54.86 \%$ companies from manufacturing and $45.14 \%$ from the banking and insurance sector. The first set of questions is related to the basic characteristics of the surveyed firms, b related to the: legal form, level of revenues achieved in 2015 and description of how the risks influenced the level of revenues they achieved in 2015, sustaining or increasing them.

Basic (dependent) variable whose observed values are directly influenced by various risks is the income (revenue) of the company.

All risk factors are considered as separate, independent statistical variables. Thus, based on the observations of the respondents, the companies and banks can accurately, quantitatively express the importance and impact of each individual risk factor on the performance of the company. The second group of questions refers to determining the factors, levels and types of risks companies managed in their risk management function.

Main Hypothesis of the research is, HO: Risk management has a positive impact on the operations of the companies, banks and insurance firms.

In order to check the hypotheses, theoretically based, statistical methods are applied: the basic methods of descriptive statistical analysis of the data under observation, the numerical characteristics of the survey, the mean value and the standard deviation; the statistical testing of the dependence of individual sample variables, where Pearson's $\chi 2$ (Chi-Square) test of the independence of certain characteristics (features, or variables) of the given sample was used.

Here, the $\chi 2$ test was used first in a statistical analysis of the structure of the sample itself, and then in determining the (no) dependence between the remaining individual responses within the observed sample. Main hypothesis, $\mathrm{H} 0$ assumes that the value of the observed 
variables does not depend on the core business performed by firms, these statistics represent an adequate measure of deviation of empirical and expected frequencies.

Therefore, "small" values are the statistics favorable to the H0 hypothesis, higher values can be the basis of this hypothesis and acceptance of the opposite hypothesis, that is, the assumption that the structure of respondents' responses directly depends on the type of activity they perform. A multiple regression analysis model was used to check the hypotheses. The basic role of this analysis is the description of the link between one output (dependent) and two or more input (independent) variables.

On the basis of the estimated values of the regression coefficients, the quality of the obtained regression bond was determined, the degree of agreement of the logistic function with the empirically obtained, obscured data. For this purpose, the following were used: the standard error of estimation, the coefficient of determination and Aikike's information criterion.

\section{Key findings}

For the purpose of this paper are given the research results for operational risk management, which covers disaster risk. In Table 3, are provided the characteristics of surveyed enterprises, banks and insurance companies.

Table 3. Characteristics of surveyed enterprises (sample)

\begin{tabular}{|c|c|c|}
\hline Description & $\begin{array}{l}\text { Percentage of } \\
\text { respondents }\end{array}$ & $\chi 2$-statistics (P-value) \\
\hline \multicolumn{3}{|c|}{ The business activity } \\
\hline Production & $54.86 \%$ & \multirow{2}{*}{$16.38(9.47 \mathrm{E}-04)$} \\
\hline Banking and Insurance & $45.14 \%$ & \\
\hline \multicolumn{3}{|c|}{ Legal form } \\
\hline Private independent company & $46.90 \%$ & \multirow{4}{*}{34.29 (1.72E-07) } \\
\hline Part of a larger system (bank) & $23.01 \%$ & \\
\hline Public company & $8.85 \%$ & \\
\hline Other & $21.24 \%$ & \\
\hline \multicolumn{3}{|c|}{ Income in 2015 (in $€$ ) } \\
\hline Less than $€ 100,000$ & $26.55 \%$ & \multirow{4}{*}{$0.805(0.8483)$} \\
\hline $100,001-500,000 €$ & $27.43 \%$ & \\
\hline $500.001-2.000 .000 €$ & $23.89 \%$ & \\
\hline More than $€ 2,000,001$ & $22.12 \%$ & \\
\hline \multicolumn{3}{|c|}{ The impact of the risk on the company's income in 2015} \\
\hline Income Sustainability (with occasional reductions) & $71.68 \%$ & \multirow{2}{*}{$5.12(0.0775)$} \\
\hline Increase revenue & $28.32 \%$ & \\
\hline
\end{tabular}

Source: Authors; 
Figure 4. Risk management of the companies according to the riks importance

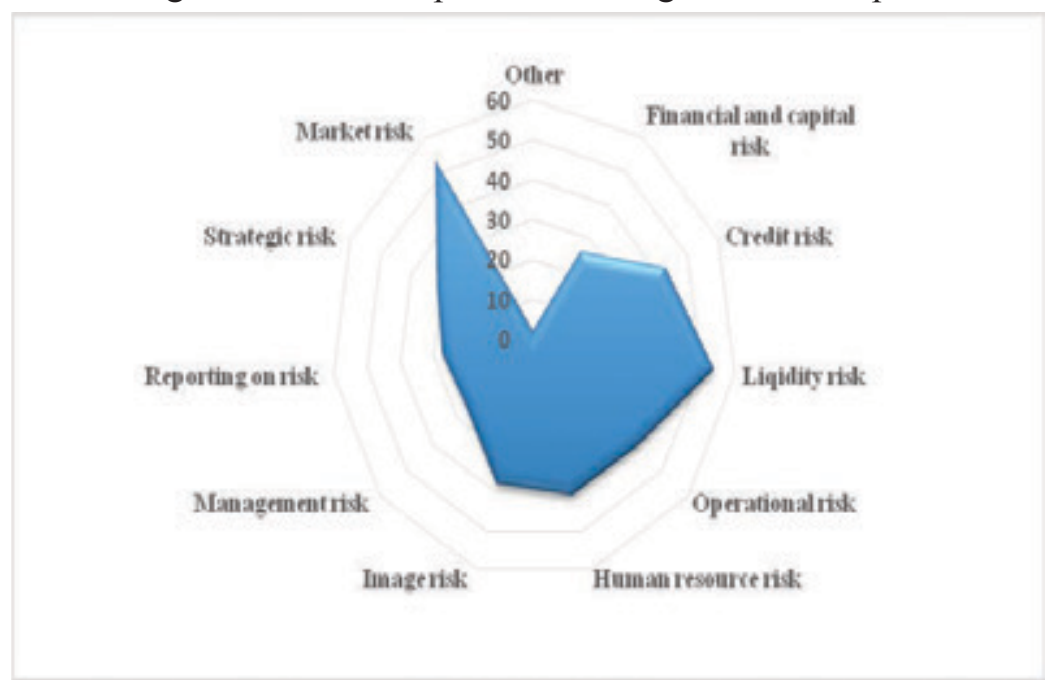

Source: Authors;

The largest number of respondents consider the liquidity risk variable the most important for their business and revenues sustainability, what is in line with the problems in the operations ( payments, loans, performing or not, economic crisis). Immediately then, the largest is followed by market risk variable.

The following significant risks for all legal entities surveyed are: credit risk, operational risks, the risks of new information technologies and the risk of human resources. For other types of risks, the representation of positive responses is somewhat smaller. The small values of all received responses are given to independent variables related to the management risk and risk of financing and capital. The distribution of positive respondents' responses to all the above issues (variables) is given in Figure 4.

Risk management of Natural disasters, floods, fires, earthquakes are treated within the operational risk. In this part, the frequency distribution, the regression dependence of a specific kind, was examined. This type of risk includes risks that may arise in different areas of business.

The effects of operational risks in the IT infrastructure (variables X1, X2, X3, X4), risks that can arise under external influences, (variables X5), Natural disasters, floods, fires, earthquakesas risks cause by climate change (X6), risks caused by lows and their changes (X7), suppliers risk (X8) and other are discussed here. All positive responses from the surveyed firms were observed as a system of nine dichotomous variables whose observer values, together with other descriptive-statistical indicators, are shown in Table 4. 
Table 4. Realized proportionality ratio (OR) values and estimated values of logistic regression coefficients

\begin{tabular}{|c|c|c|c|c|c|}
\hline Variables & & & OR & $\begin{array}{l}\text { Regression } \\
\text { coefficients }\end{array}$ & $\begin{array}{l}\text { Standard } \\
\text { error }\end{array}$ \\
\hline $\begin{array}{l}\text { Regression } \\
\text { constant }\end{array}$ & & & & 0.3525 & $8.37 E-02$ \\
\hline$X_{1}$ & $\begin{array}{l}\text { Plan renewal of II } \\
\text { introduction of ne }\end{array}$ & $\begin{array}{l}\text { uipment and software, } \\
\text { nodels }\end{array}$ & 3.7083 & 0.0591 & $6.82 E-02$ \\
\hline$X_{2}$ & Level of security & ne information system & 0.9483 & 0.0985 & $5.55 E-02$ \\
\hline$X_{3}$ & A downturn in bus & ss and system crashes & 0.7656 & -0.0233 & $5.76 E-02$ \\
\hline$X_{4}$ & Damage to assets & equipment & 0.7385 & 0.0780 & $5.55 E-02$ \\
\hline$X_{5}$ & External theft / un & dictable external events & 0.4675 & 0.0699 & $5.82 E-02$ \\
\hline$X_{6}$ & Natural disasters & oods, fires, earthquakes & 0.5270 & 0.0056 & $6.13 E-02$ \\
\hline$X_{7}$ & Laws & & 0.3951 & 0.0059 & $5.95 E-02$ \\
\hline$X_{8}$ & Suppliers & & 0.2418 & -0.0233 & $7.31 E-02$ \\
\hline$X_{9}$ & Other & & 0.0367 & -0.0743 & $3.06 E-01$ \\
\hline \multicolumn{2}{|c|}{ Total error rating $(Q)$ : } & 0.2972 & & & \\
\hline \multicolumn{2}{|c|}{ Determination coefficient $\left(R^{2}\right)$ : } & 0.7645 & & & \\
\hline \multicolumn{2}{|l|}{ AIC: } & 50.251 & & & \\
\hline
\end{tabular}

Source: work of authors.

Using the binomial logistic regression model, the influence of the Natural disasters, floods, fires, earthquakes as dichotomous variable on the total amount of realized income of surveyed firms in 2015 is determined as of small impact (Table 4).

\section{Discussion and Conclusions}

Key findings of the flood disaster happened in 2014 show that no disaster risk financing strategy currently was in place, there were limited number of instruments available, Government relied largely on ex-post instruments: budget reallocation, emergency borrowing, donor financing, and an insufficiency of available financing has been evident with a significant resource gap identified to cover recurrent losses.

From the field research the eestimated values of the parameters of the corresponding regression model, together with OR-coefficients given in the vertical indices show that manufacturing companies, and banks as well as insurance companies still are not aware enough on climate change risks, and these risks are not payed adequate attention in risk management policy of the firms. 
So both, institutional-national and companies level of planning, managing and reporting on disaster risk is not on the level that climate change would propose.

Budget system does not allow the accumulation of resources over a multiyear period, cash accounting principle was not function as all the funds were not spent during one year and cannot be used in the next period and accumulated. The lack of fiscal space from ongoing fiscal consolidation efforts pursued by the Government was evident, as well as the high competition for financing resources, difficult to set aside considerable amounts of budgetary resources for contingencies.

It can be concluded that, in a better preparation of a catastrophe an promotion of catastrophe financing and insurance for individuals and activities for boosting private insurance sales under way would be needed, analysis of various budget protection mechanisms (national and local level), and more developed risk management plans and strategies of banking, insurance sector and enterprises on long term, reducing complexity and increasing certainty.

Serbia would have to address pervasive underinsurance of disaster risks through communications initiatives and forms of indirect compulsion ( Michel - Kerjan, 2010;) as: encouraging risk awareness, improving policyholder awareness of their level of protection, indirect compulsion for a higher levels of flood insurance purchase at the time of acquisition, flood insurance policies.

General protection against floods following intense local precipitation is not feasible. Instead of quantitative forecasts qualitative warnings would be welcomed. Structural precaution is easily possible for newly constructed buildings, but hardly feasible (and expensive) for existing buildings. Values do increase as the climate change is happening and the risk from flash floods will increase as complex processes and prevention with cooperation is seen as a long term multidisciplinary value chain activity.

\section{References}

1. Ahern, M., Kovats, R., Wilkinson, P. (2005): Global health impact of floods: epidemiological evidence. Epidemiologic Reviews, Vol. 27, No. 1, pp. 36-46.

2. Baxter, P. (2005): The east coast big flood, 31 January-1 February 1953: A summary of the human disaster. Philosophical Transactions: Mathematical, Physical and Engineering Sciences (Series A), Vol. 363(1831), pp.1293-1312.

3. Beyhun, N., Altintas, K., Noji, E. (2005): Analysis of registered floods in Turkey. International Journal of Disaster Medicine, Vol. 3, No.1-4, pp. 50-54.

4. Bich, T., Quang, L., Ha, L., Hanh, T., Guha-Sapir, D. (2011): Impacts of flood on health: epidemiologic evidence from Hanoi, Vietnam. Global Health Action, Vol.4, pp. 63-56.

5. Biswas, A., Rahman, A., Mashreky, S. (2010): Unintentional injuries and parental violence against children during flood: a study in rural Bangladesh. Rural and Remote Health, Vol. 10, pp.11-99.

6. Cariappa, M., and Khanduri, P. (2003): Health emergencies in large populations: 
The Orissa experience. Medical Journal of the Armed Forces of India, Vol. 59, No. 4, pp. 286-289.

7. Centers for Disease Control and Prevention(CDC).(2001): Morbidity and Mortality, Weekly Report, Vol. 49, No. 7, pp. 133-135.

8. FitzGerald, G., Du, W., Jamal, A. (2010): Flood fatalities in contemporary Australia (1997-2008). Emergency Medicine Australasia, Vol. 22, pp.80-186.

9. Gerritsen, H. (2005): What happened in 1953? The big flood in the Netherlands in retrospect. Philosophical Transactions: Mathematical, Physical and Engineering Sciences (Series A), Vol. 363(1831) pp.1271-1291.

10. Guzzetti, F., Stark, C., Salvati, P. (2005): Evaluation of flood and landslide risk to the population of Italy. Environmental Management, Vol. 36, No.1, pp.15-36.

11. Jonkman, S., and Kelman, I. (2005): An analysis of the causes and circumstances of flood disaster deaths. Disasters, Vol. 29, No. 1, pp. 75-97.

12. Jonkman, S. (2005): Global perspectives on loss of human life caused by floods. Natural Hazards, Vol. 34, No.2, pp. 151-175.

13. Kundzewicz, Z., Kanae, S., Seneviratne, S. (2014): Flood risk and climate change: global and regional perspectives. Hydrol. SCI Journal, Vol. 59, No. 1, pp. 1-28.

14. Lastoria, B., Simonetti, M., Casaioli, M. (2006): Socio-economic impacts of major floods in Italy from 1951 to 2003. Advances in Geosciences, Vol. 7, pp. 223-229.

15. Jonkman, S., Maaskant, B., Boyd, E. (2009): Loss of life caused by the flooding of New Orleans after Hurrican Katrina: Analysis of the relationship between flood characteristics and mortality. Risk Analysis, Vol. 29, No. 5, pp. 676-698.

16. Jonkman, S., and Vrijling, J. (2008): Loss of life due to floods, Journal of Flood Risk Management, Vol. 1, pp. 43-56.

17. Lllewellyn, M. (2006): Floods and Tsunamis. Surgical clinics of North America, Vol. 86, pp. 557-578.

18. Melecky, M., Raddatz, C. (2011); How do Governments respond after Chatstrophes? Natural disaster shocks and the fiscal stance, Policy research working paper, No.5564, World Bank, Washington, available at: https://blogs.worldbank.org

19. Michel-Kerjan, E. (2010): Catastrophe economics: the national flood insurance program, Journal of economic perspectives, Vol.24, No. 4, pp. 165-186.

20. Ogden, C., Gibbs-Scharf, L., Kohn, M. (2001): Emergency health surveillance after severe flooding in Louisiana, Prehospital and Disaster Medicine, Vol. 16, No. 3, pp.138-144

21. Pradhan, E., West, K., Katz, J. (2007): Risk of flood-related mortality in Nepal. Disasters, Vol. 31, No. 1, pp. 57-70.

22. Rashid, S. (2000): The urban poor in Dhaka city: Their struggles and coping strategies during the floods of 1998. Disasters, 24(3); 240-253.

23. Schnitzler, J., Benzler, J., Altmann, D. (2007): Survey on the population 's needs and 
the public health response during floods in Germany. Public Health Management and Practice, Vol. 13, No. 5, pp.461-464.

24. Spencer, J., and Myer, R. (2007): Population and economic overview of Cambria County, Pennsylvania following the 1977 Johnstown flood. Disaster Prevention and Management, Vol. 16, No. 2, pp. 259-264.

25. Tarhule, A. (2005): Damaging rainfall and flooding: The other Sahel hazards. Climatic Change, Vol. 72, No. 3, pp. 355-377.

26. Von Peter, G., von Dahlen, S., Saxsena, S.(2012): Unmitigated disasters? New evidence on the macroeconomic cost of natural catstrophes, BIS working papers, No. 394, Bank for international settlements, available at: www.bis.org

27. Yale, J., Cole, T., Garrison, H. (2003): Motor vehicle-related drowning deaths associated with inland flooding after Hurricane Floyd: A field investigation. Traffic Injury Prevention, Vol. 4, No. 4, pp. 279-284. 


\title{
UNAPREĐENJE OTPORNOSTI OSIGURANJA I FINANSIJA U KONTEKSTU KLIMATSKIH PROMENA
}

\author{
Miroslav Miškičc ${ }^{4}$ Goran Ćorič ${ }^{5}$, Danijela Vukosavljevićc
}

\begin{abstract}
Sažetak
Ključni izazov za pojedince, preduzeća $i$ vlade biće izgradnja finansijske otpornosti $i$ osiguranja od klimatskih promena. Ovo postaje važnim pitanjem za finansijski menadžment da kreira finansijsku zaštitu i sredstva osiguranja za upravljanje finansijskim gubicima, smanjujući ekonomski uticaj prirodnih katastrofa i omogućavajući bolji oporavak od njih. U tom smislu ovaj rad daje pregled rezultata terenskog i desk istraživanja klimatskih promena $s$ aspekta finansijskog upravljanja njihovim potencijalnim uticajem na prihode i gubitke. Desk istraživanje bazira na primeru Srbije i njenim iskustvom u poplavama iz 2014. godine. Uradu su prikazani i glavni rezultati terenskog istraživanja sprovedenog u Srbiji 2016. godine u 92 proizvodne firme, banke i osiguravajuća društva o upravljanju rizikom prirodnih nepogoda, poplava, požara i zemljotresa, kao sastavnim delom organizacionog rizika. Korišćene su statističke metode deskripcije, $X^{2}$ testa i lienearne regresije. Rezultati oba istraživanja o upravljanju rizikom poplava su pokazala da: kompanije kalkulišu mali uticaj ovog rizika na njihove prihode, kao i vidljiv ne strateški pristup srpske vlade kroz nedostatak $65 \%$ sredstava u pokrivanju gubitaka od ovog rizika. Istraživanje takođe upućuje na nizak nivo svesti o ovom problem 2014. godine na nacionalnom i korporativnom nivou. Doprinos rada se ogleda u podršci razvoju budućih nacionalnih I lokalnih planova za efikasnije smanjenje prekida ekonomskih aktivnosti zbog prirodnih nepogoda i politici uvođenja finansiranja $i$ osiguranja od nepogoda, povećanja kapaciteta tržištao siguranja da apsorbuje ove rizike, kao i podršci unapređenju kulture upravljanja rizikom u ovoj oblasti.
\end{abstract}

Ključne reči: Upravljanje rizikom, rizik od poplava, banke, osiguranje,klimatske promene

4 Docent,drMiroslavMiškić,UniverzitetuNovomSadu,Fakultettehničkihnauka,TrgDositejaObradovića br. 6, 21000 Novi Sad, Srbija, Telefon: +381 65511 233, E-mail: miroslav.miskic@outlook.com; smerada@hotmail.com

5 Mr Goran Ćorić, doktorant, Univerziteta Sigidunum u Beogradu, Ulica Danijelova br. 32, 11000 Beograd, Srbija, Telefron. +381 63264 496, E-mail: coric.g7@gmail.com.

6 Docent, dr Danijela Vukosavljević, Univerzitet Union "Nikola Tesla” u Beogradu, Fakultet za menadžment, Sremski Karlovci, Njegoševa ulica br. 1a, 21205 Sremski Karlovci, Srbija, Telefon: +381 6220962 50, E-mail: dr.danijela.vukosavljevic@gmail.com.

EP 2017 (64) 3 (1019-1033) 